\title{
ALLOMETRIC MODELS TO ESTIMATE ABOVEGROUND BIOMASS OF SMALL TREES IN WET TROPICAL FORESTS OF COLOMBIAN PACIFIC AREA $^{1}$
}

\author{
Milena A. Segura ${ }^{2 *}$, Luis Miguel Acuña ${ }^{2}$ and Hernán J. Andrade ${ }^{3}$
}

\footnotetext{
${ }^{1}$ Received on 02.06.2017 accepted for publication on 02.05.2018.

${ }^{2}$ Universidad del Tolima, Facultad de Ingeniería Forestal, Colômbia. E-mail: $<$ masegura@ut.edu.co $>$ and $<$ Imacunas@ut.edu.co $>$.

${ }^{3}$ Universidad del Tolima, Facultad de Ingeniería Agronómica, Colômbia. E-mail: < hjandrade@ut.edu.co $>$.

*Corresponding author.
}

\begin{abstract}
World wet tropical forests, and especially the ones in the Colombian Pacific area, are the target of a small tree (minor diameter) selective harvest process, used in short-cycle industries, such as bioenergy. This situation generates a reduction in stored carbon and biomass, and becomes an emission of greenhouse gases (GHG). Allometric models for aboveground biomass are few, despite being an important tool of carbon calculation. The goal of this study was to develop multi-species allometric models for small trees aboveground biomass in wet tropical forests. A total of 61 individuals (diameter at breast height -DBH- $<12 \mathrm{~cm}$ ) was measured, cut and weighed to estimate their biomass. The model with the best adjustment was selected considering criteria of determination coefficient $\left(\mathrm{R}^{2}\right)$ and adjusted $\mathrm{R}^{2}$, mean quadratic error of prediction, Akaike and Bayesian Information Criteria and the biological logic of the model. Best-fit allometric model $\left(\mathrm{R}^{2}=0,72\right)$ was with $\mathrm{DBH}$ and total height as independent variables, considering that it is a multi-species model coming from forests with a high diversity.
\end{abstract}

Keywords: Forest harvest; Carbon; Mitigation.

\section{MODELOS ALOMÉTRICOS PARA ESTIMAR A BIOMASA AÉREA DE ÁRVORES PEQUENAS EM BOSQUES HÚMIDOS TROPICAIS DO PACÍFICO COLOMBIANO}

\begin{abstract}
RESUMO - Os bosques do trópico húmido no mundo e, especialmente os do Pacífico Colombiano, estão a ser submetidos a um aproveitamento selectivo de árvores de diâmetros menores, utilizados em indústrias de ciclos curtos, tal como a bioenergía. Esta situação gera uma redução na biomasa e o carbono alojado e constitui-se numa emissão de gases de efeito invernadero (GEI). Os modelos alométricos para a estimativa da biomasa acima do solo de árvores pequenas são escassos, apesar de ser uma importante ferramenta para o cálculo do carbono. O objectivo do estudo foi desenvolver modelos alométricos multi-espécies para estimar a biomasa acima do solo em bosques húmidos tropicais. Seleccionaram-se 61 indivíduos (diâmetro à altura do peito -DAP- $<12 \mathrm{~cm}$ ), que eles foram medidos, cortado e pesado para estimar a sua biomassa. Seleccionouse o modelo de melhor ajuste considerando critérios de coeficiente de determinação $\left(R^{2}\right)$ e $R^{2}$ ajustado, erro quadrático médio de predição, Critérios de Akaike e Bayesiano de Informação e a lógica biológica do modelo. Alométrica modelo melhor ajuste $\left(R^{2}=0,72\right)$ foi a DAP e altura total como variáveis independentes, considerando que é um multi-espécies de florestas com um modelo de elevada diversidade.
\end{abstract}

Palavras-Chave: Aproveitamento florestal; Carbono; Mitigação. 


\section{INTRODUCTION}

Forests play a specific and very important role in the global carbon-cycle, absorbing carbon dioxide during photosynthesis and storing it above and belowground (Ilyas, 2013). A mechanism of mitigation and adaptation to climate change are the projects of Reduction of Emissions from Deforestation and Forest Degradation (REDD + ) as a political-effective option. One of its goals is to estimate the carbon reserves stored in the forests (Field et al, 2014). The existence of local allometric models to estimate biomass in different land uses is a fundamental part of the carbon inventories, and these are a basic requirement to develop forest projects for greenhouse gases (GHG) mitigation. Forest biomass has been studied with different purposes, among which is the nutrient cycle, for energetic purposes, in forest growth assessment, for forest management purposes, environmental impact mitigation, and obtaining economic incentives for forest preservation and the reduction of such gases (Sanquetta et al., 2014). Being aware that forest cover is the main carbon sink, these ecosystems are considered as a climatic change mitigation strategy at global level (FAO, 2010; Banco Mundial, 2018). The main threat to conservation of forests in Bajo Calima, Valle del Cauca and Colombian Pacific is the indiscriminate tree harvest of the commercial species most appreciated by the community (Programa de las Naciones Unidas para el Desarrollo [United Nations Development Program] PNUD, 2010), which has caused forest destruction and a modification in the landscape that may start biodiversity degradation (Martínez, 2007).

The Bajo Calima population, mostly of Africandescending and organized into Community Councils, is searching for sustainable alternatives for their forests protection. This population, just like many others in the Colombian Pacific, due to its environmental and socio-economic characteristics, are mainly dependent on wood products such as beams, poles and posts of minor diameters that are used in mines and for their sustenance as firewood (Programa de las Naciones Unidas para el Desarrollo - PNUD, 2010). From 2013, A REDD+ project was started in Bajo Calima and Bahía Malaga with the purpose of reducing climatic change and contribute to the conservation of biodiversity, increasing sustainable development of the local communities (Verified Carbon Standard -VCS-, 2015).

Allometric models allow estimating biomass based on variables measured in forest inventories (diameter at breast height $-1,3 \mathrm{~m}$ from ground, $\mathrm{DBH}-$ and total height - TH - or at canopy base - $\mathrm{CBH}$ ) (Andrade et al., 2014). However, biomass models are specific for each type of ecosystem, life zone, species or group of species (Segura and Kanninen, 2005; Picard et al., 2012; Andrade et al., 2014). Therefore, local models are a good practice according to IPCC (2006). Allometric models by Chave et al. (2005) and Álvarez et al. (2012) comprise a good approximate to estimate aboveground biomass of tropical forests in regions where no models have been developed, since these are few or non-existent in the Colombian Pacific.

Multi-species allometric models, developed with representative species of a forest, in order to estimate biomass in individuals of minor diameters ( $\mathrm{DBH}<10$ $\mathrm{cm})$ are more scarce than for trees $(\mathrm{DBH} \geq 10 \mathrm{~cm})$, such as the ones developed by Álvarez et al. (2012) for Colombian natural forests and the ones by Brown et al. (1989), Chave et al. (2005) and Nelson et al., (2014) for tropical forests. A few models for minor individuals include the ones produced by Andrade et al., (2008) for saplings and seedlings $(0,3 \mathrm{~cm}<\mathrm{DBH}<10 \mathrm{~cm})$ in high fallows in the tropical zone in Talamanca, Costa Rica and by Hughes et al., (1999) for trees with DBH $<10 \mathrm{~cm}$ in secondary forests on wet tropics in Tuxtla, México.

The goal of this research was to develop a multispecies allometric model to estimate total aboveground biomass of minor diameter individuals $(\mathrm{DBH}<12 \mathrm{~cm})$ in forests intervened in Bajo Calima, and the Colombian Pacific.

\section{MATERIALS AND METHODS}

\subsection{Area of study.}

The research was carried out in the Consejo Comunitario de la Cuenca del Bajo Calima (CCCBC), more specifically in the communities of La Estrella, Las Brisas, El Crucero km 9, Villa Estela and San Isidro. $\mathrm{CCCBC}$ is located in the coordinates $03^{\circ} 57^{\prime} 12,7^{\prime \prime} \mathrm{N}$ and $76^{\circ} 59^{\prime} 26,6^{\prime \prime} \mathrm{W}$, at an altitude of $50 \mathrm{~m}$ and at approximately $20 \mathrm{~km}$ from the Municipality of Buenaventura. The area of study is characterized for presenting an annual mean temperature and precipitation of $26^{\circ} \mathrm{C}$ and $7184 \mathrm{~mm}$, respectively, a mean relative humidity of $88 \%$ and a $966 \mathrm{~h} /$ year of sunlight (Instituto de Hidrología, Meteorología y Estudios Ambientales [Hydrology, Meteorology and Environmental Studies Institute] -(IDEAM, 2016).

Revista Árvore. 2018;42(2):e420209 


\subsection{Selection of species and individuals.}

The species selected for the construction of the multi-species allometric models were the ones with the highest commercial use in the zone. According to Lozano and González (2011), the major timber products obtained from these secondary forests are around woods in shapes of beams, poles, logs and posts, whose commercialization is focused mainly in small individuals (4 to 5 years old) with a DBH between 8 and $15 \mathrm{~cm}$.

A total of 61 individuals were sampled, which were harvested by the communities, and belonging to 25 species and 17 families: Protium colombianum Cuatrec. (Burseraceae), Calophyllum mariae Planch. \& Triana (Clusiaceae), Mabea chocoensis Croizat and Tetrorchidium ochroroleucum Cuatrec. (Euphorbiaceae), Casearia oblongifolia Cambess. (Saliacaceae), Goupia glabra Aubl. (Goupiaceae), Humiria sp (Humiriaceae), Ocotea cernua (Nees) Mez y Ocotea sp (Lauraceae), Eschweilera sp (Lecythidaceae), Abarema sp and Inga chocoensis T.S. Elias (Leguminoseae), Pterygota excelsa (Standl. \& L.O. Williams) Kosterm; and Sterculia pilosa Ducke (Malvaceae), Miconia lepidota Schrank \& Mart. ex DC. And Miconia sp (Melastomataceae), Otoba lehmannii (A.C. Sm.) A.H. Gentry and Virola sp (Myristicaceae), Ogcodeia ulei (Warb.) J.F. Macbr., Chrysophyllum sp and Pouteria sp (Sapotaceae), Simarouba amara Aubl. (Simaroubaceae), Pourouma aspera Trécul (Urticaceae), Qualea lineata Stafleu and Vochysia ferruginea Mart. (Vochysiaceae). The individuals selected were classified as seedlings (DBH $<5 \mathrm{~cm}$ and $\mathrm{TH} \geq 0,3 \mathrm{~m})$, saplings $(5 \leq \mathrm{DBH}<10 \mathrm{~cm})$ and trees $(10 \leq \mathrm{DBH}<12 \mathrm{~cm})$.

\subsection{Measuring and biomass estimation.}

Once the sampled trees were selected and taxonomically identified, its $\mathrm{DBH}, \mathrm{TH}$ and $\mathrm{CBH}$ were measured. The individuals were cut and separated in three components: stem, large branches (diameter $>$ $2 \mathrm{~cm}$ ), small branches (diameter $\leq 2 \mathrm{~cm}$ ) and leaves, every one of each was weighed by taking two subsamples (of approximately $250 \mathrm{~g}$ each) to estimate dry matter $\left(60^{\circ} \mathrm{C}\right.$ until constant weight). Then, total aboveground biomass $(\mathrm{Bt})$ per individual, adding the biomass of all components, was estimated.

\subsection{Allometric model selection.}

Pearson correlation coefficient ( $r$ ) between the dependent $(\mathrm{Bt})$ and independent variables $(\mathrm{DBH}, \mathrm{TH}$ and $\mathrm{CBH}$ ) was calculated. Then, linear regression analysis with and without logarithm transformations were carried out. The best models were selected considering the criteria of: highest determination coefficient $\left(\mathrm{R}^{2}\right)$ and adjusted $\mathrm{R}^{2}$, lowest mean quadratic error of prediction (ECMP), Akaike Information Criteria (AIC) and Bayesian Information Criteria (BIC) and the models biological logic (Clutter et al., 1983; Segura and Andrade, 2008; Andrade et al., 2014). Just the same, an analysis of estimated $v s$ observed and residuals was carried out for the selected models.

The models with the best adjustment were compared with the ones developed in tropical wet and very wet forests of America, Asia and Oceania used for Colombia with DBH $>10 \mathrm{~cm}$ (Eq. 1; Chave et al., 2005) and or those for $\mathrm{DBH}<10 \mathrm{~cm}$ developed in Costa Rica (Eq. 2; Andrade et al., 2008) and Mexico (Eq. 3; Hughes et al., 1999).

$$
\begin{array}{ll}
\operatorname{Ln}(B t)=-3,08+1,007 * \operatorname{Ln}\left(\mathrm{DBH}^{2 *} \mathrm{TH}^{*} \mathrm{~g}\right) & \text { [Eq. 1] } \\
\log (\mathrm{Bt})=-1,27+2,2 * \log (\mathrm{DBH}) & \text { [Eq. 2] } \\
\operatorname{Ln}(\mathrm{Bt})=\left(4,94+1,06 * \operatorname{Ln}\left(\mathrm{DBH}^{2}\right)^{*} 1,14\right) / 1000 & \text { [Eq. 3] }
\end{array}
$$

Where; Ln: natural logarithm; Log: base-10 logarithm; Bt: total aboveground biomass ( $\mathrm{kg} /$ tree); DBH: diameter at breast height (cm); TH: total height $(\mathrm{m}) ; g$ : specific gravity of wood $\left(\mathrm{g} / \mathrm{cm}^{3}\right)$.

Specific gravity was used per species or genus reported in the wood density global database Zanne et al. (2009); while for the rest of the species, a value of $0,6 \mathrm{~g} / \mathrm{cm}^{3}$, recommended by IPCC (2006) for tropical America, was used.

\section{RESULTS}

\subsection{Features of sampled individuals.}

Sampled individuals showed a DBH range from 2,0 to $12,0 \mathrm{~cm}$, a TH of 3,9 to $15,3 \mathrm{~m}$ and a $\mathrm{Bt}$ that varied between 0,8 and $42,6 \mathrm{~kg} /$ tree. Calophyllum mariae, Abarema sp, Miconia sp and Chrysophyllum sp are represented in all diametric classes (Table 1), which probably explains their high natural regeneration natural and the strong harvest pressure to which are being object of. Sampled trees showed a mean Bt of 17,9 kg/ tree, from which $60 \%$ was found in the stems (Table 1). In contrast, leaf biomass from the sampled trees varied between 0,1 and $10,7 \mathrm{~kg} /$ tree, making the $15 \%$ of the Bt (Table 1). 


\subsection{Correlation between variables.}

Bt was best correlated with $\mathrm{TH}$ and $\mathrm{DBH}$ than with $\mathrm{CBH}(\mathrm{r}=0,77 ; \mathrm{r}=0,69$ and $\mathrm{r}=0,52$, respectively; Figure 1$)$. Just as expected, stem biomass was better explained by $\mathrm{DBH}$ than by $\mathrm{TH}$ or $\mathrm{CBH}(\mathrm{r}=0,78 ; \mathrm{r}=0,76$ and $r=0,55$, respectively).

\subsection{Model adjustment.}

The best fit multi-species models to estimate $\mathrm{Bt}$ are based on $\mathrm{TH}, \mathrm{DBH}$, or in the combination of these two variables (Table 2). These models turned out to be the best according to the statistics used and were logical from the biologic point of view. The best multispecies model includes the combination of TH and $\mathrm{DBH}$ as independent variables $\left(\mathrm{R}^{2}=0,72\right)$; meanwhile those with only one variable show adjusted $\mathrm{R}^{2}$ for $\mathrm{DBH}$ and $\mathrm{TH}\left(\mathrm{R}^{2}=0,63 ; \mathrm{R}^{2}=0,65\right.$, respectively) (Table 2 ) for the sizes of the sampled trees.

Despite the models fit a variety of species in forests with a structural diversity, these equations show good adjustments $\left(0,63<\mathrm{R}^{2}<0,72\right)$ and the estimates are relatively similar to observed biomass (Figure 2). However, AIC and BIC criteria allow verifying a good model adjustment. The comparative analysis of estimated $v s$ observed biomass, along the statistics, indicate that the best-adjustment model was the one that includes DBH and TH variables (Eq. 4; Figure 2), which estimates sampled trees biomass with a higher precision than those based exclusively on one of these variables. Figure 2 shows the best-fit models in each of the independent variables separately and one with both together, whose error distribution can be detailed in the corresponding residual graphics.

Chave et al. (2005), Andrade et al. (2014) and Hughes et al. (1999) equations underestimate aboveground biomass of small-diameter trees sampled (Figure 3 ). In the case of the second model mentioned, estimations are far below the data observed of the sampled trees. However, first model estimates are closer to those carried out with the model of the Eq. 4, which was generated in this study.

\section{DISCUSSION}

Commonly, a high correlation between DBH and stem and large branches biomass is expected in established and well-formed individuals. It is not the case between $\mathrm{DBH}$ and leaves or small branches biomass in small individuals ( $\mathrm{DBH}<15 \mathrm{~cm}$ ) (Segura and Andrade, 2008). This implies that the models to be developed must include TH or DBH as independent variable, depending on the size of the trees and the dependent variable (biomass components). In general, and as shown in some previous research, $\mathrm{DBH}$ is the variable that best correlates and predicts biomass (Brown et al., 1989; Chave et al., 2005; Segura and Kanninen, 2005). Besides, this variable is easy to measure and registers in most forestry inventories (Segura and Kanninen,

Table 1 - Dasometric and taxonomic characteristics and biomass of the sampled trees for the development of biomass models for small trees $(\mathrm{DBH}<12 \mathrm{~cm})$ in forests of the Bajo Calima, Buenaventura, Colombia.

Tabela 1 - Características dasométricas, taxonómicas e biomasa dos indivíduos muestreados para o desenvolvimento de modelos de biomasa para árvores pequenas $(D A P<12 \mathrm{~cm}$ ) em bosques de o Bajo Calima, Buenaventura, Colombia.

\begin{tabular}{|c|c|c|c|c|c|c|c|c|}
\hline \multirow{2}{*}{$\begin{array}{c}\text { Diametric } \\
\text { class } \\
(\mathrm{cm})\end{array}$} & \multirow[t]{2}{*}{$\begin{array}{c}\text { \# of } \\
\text { individuals }\end{array}$} & \multirow[t]{2}{*}{ Species } & \multirow[t]{2}{*}{$\mathrm{DBH}(\mathrm{cm})$} & \multirow[t]{2}{*}{$\mathrm{TH}(\mathrm{m})$} & Bs & $\mathrm{Bb}$ & \multirow[t]{2}{*}{$\mathrm{B} 1$} & \multirow[t]{2}{*}{$\mathrm{Bt}$} \\
\hline & & & & & \multicolumn{2}{|c|}{$\mathrm{kg} /$ tree } & & \\
\hline $2,0-4,9$ & 21 & $\begin{array}{c}1,2,3,4,5,6,9,11, \\
13,14,16,20,21,24,25\end{array}$ & $3,6 \pm 0,1$ & $6,3 \pm 1,4$ & $2,9 \pm 0,5$ & $1,9 \pm 0,4$ & $1,4 \pm 0,3$ & $6,3 \pm 1,1$ \\
\hline $5,0-10,0$ & 24 & $\begin{array}{c}1,2,3,5,6,10,11,12, \\
13,15,16,18,19,20,21,25\end{array}$ & $6,5 \pm 0,1$ & $8,7 \pm 0,3$ & $6,8 \pm 1,4$ & $4,0 \pm 0,7$ & $3,0 \pm 0,6$ & $18,8 \pm 2,0$ \\
\hline $10,0-11,9$ & 16 & $\begin{array}{c}2,8,9,10,11,14,15 \\
16,18,20\end{array}$ & $9,7 \pm 0,2$ & $10,8 \pm 0,5$ & $20,7 \pm 1,6$ & $7,7 \pm 0,9$ & $3,0 \pm 0,7$ & $31,5 \pm 1,7$ \\
\hline Total & 61 & 25 & $6,3 \pm 0,3$ & $8,4 \pm 0,3$ & $11,0 \pm 1,1$ & $4,3 \pm 0,4$ & $2,5 \pm 0,3$ & $16,7 \pm 11,6$ \\
\hline
\end{tabular}

DBH: Diameter at breast height; TH: total height; Bfs: biomass of stems; Bb: biomass of branches; Bl: biomass of leaves; Bt: total aboveground biomass. Values correspond to mean \pm standar error. 1: Protium colombianum; 2 : Calophyllum mariae; $3:$ Mabea chocoensis; $4:$ Tetrorchidium ochloroleucum; 5: Casearia oblongifolia; 6: Goupia glabra; 7: Humiria sp; 8: Ocotea cernua; 9: Ocotea sp; 10: Eschweilera sp; 11: Abarema sp; 12: Inga chocoensis; 13: Pterygota excelsa; 14: Sterculia pilosa; 15: Miconia lepidota; 16: Miconia sp; 17: Otoba lehmannii; 18: Virola sp; 19: Ogcodeia ulei; 20: Chrysophyllum sp; 21: Pouteria sp; 22: Simarouba amara; 23: Pourouma aspera; 24: Qualea lineata; 25: Vochysia ferruginea.

Revista Árvore. 2018;42(2):e420209 

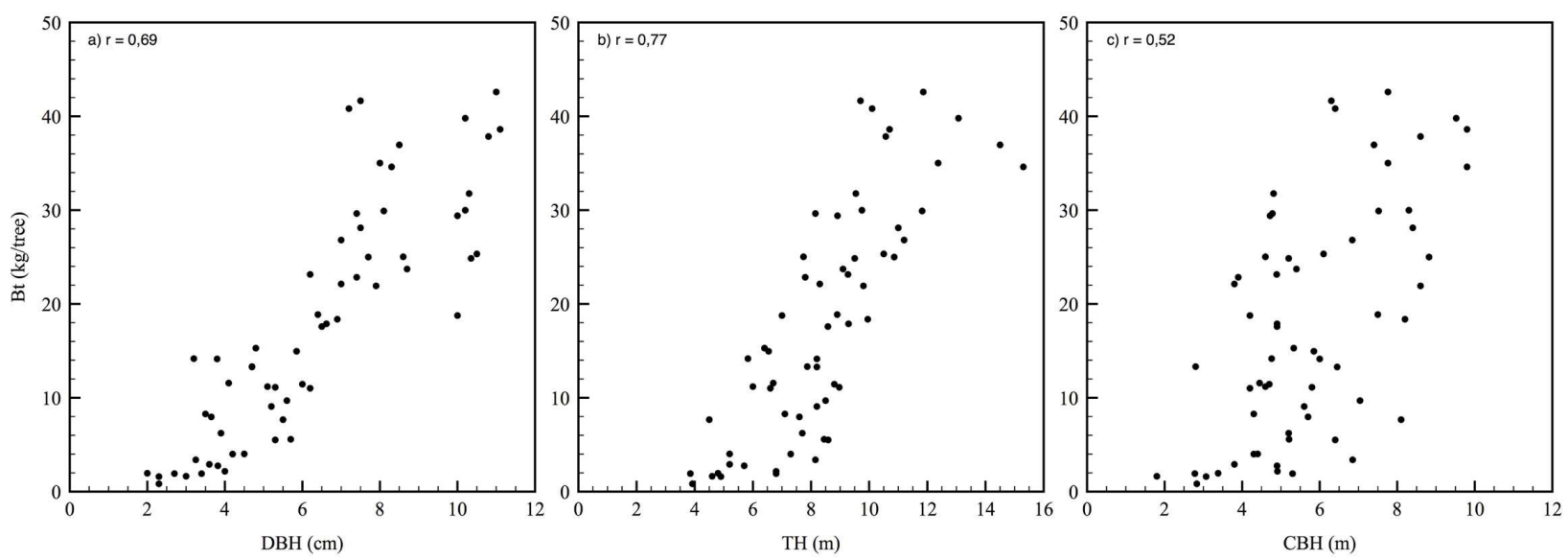

Figure 1 - Relationship between total aboveground biomass and the independent variables (a: DBH; b: TH; c: CBH) of small trees $(\mathrm{DBH}<12 \mathrm{~cm})$ in the Consejo Comunitario de la Cuenca del Bajo Calima, Buenaventura, Valle del Cauca, Colombia. DBH: diameter at breast height; TH: total height; $\mathrm{CBH}$ : canopy base height.

Figura 1 - Relação entre a biomasa aérea total e as variáveis independentes (A: DAP; B: HT; C: HBC) de árvores pequenas $(D A P<12 \mathrm{~cm})$ em o Consejo Comunitario de la Cuenca del Bajo Calima, Buenaventura, Valle del Cauca, Colombia.

Table 2 - The best-fit alometric models for estimating total aboveground biomass of small trees $(\mathrm{DBH}<12 \mathrm{~cm})$ in forests of the Consejo Comunitario de la Cuenca del Bajo Calima, Buenaventura, Valle del Cauca, Colombia.

Tabela 2 - Modelos alométricos de melhor ajuste para a estimativa da biomasa aérea total de árvores pequenas (DAP $<12 \mathrm{~cm}$ ) em bosques de o Consejo Comunitario de la Cuenca del Bajo Calima, Buenaventura, Valle del Cauca, Colombia.

\begin{tabular}{lccccc}
\hline \multicolumn{1}{c}{ Model } & $\mathrm{R}^{2}$ & $\mathrm{R}^{2} \mathrm{Aj}$ & $\mathrm{ECMP}$ & $\mathrm{AIC}$ & $\mathrm{BIC}$ \\
\hline Eq.4Ln(Bt) $=-2,42+0,93 * \operatorname{Ln}(\mathrm{DBH})+1,52 * \operatorname{Ln}(\mathrm{TH})$ & 0,72 & 0,71 & 0,29 & 96,7 & 105,1 \\
Eq.5Ln(Bt) $=-0,68+1,74 * \operatorname{Ln}(\mathrm{DBH})$ & 0,63 & 0,63 & 0,35 & 111,3 & 117,6 \\
Eq.6Ln(Bt) $=-3,02+2,59 * \operatorname{Ln}(\mathrm{TH})$ & 0,65 & 0,64 & 0,35 & 109,2 & 115,5 \\
\hline
\end{tabular}

Ln: natural logarithm; Bt: total aboveground biomass (kg/tree); DBH: diameter at breast height (cm); TH: total height (m); ${ }^{2}$ : determination coefficient; $\mathrm{R}^{2} \mathrm{Aj}$ : adjusted $\mathrm{R}^{2}$; ECMP: mean quadratic error of prediction; AIC: Akaike's Information Criterion; BIC: Bayesian Information Criterion.

2005; Fonseca et al., 2009). However, in small individuals, total biomass can also be very well explained by $\mathrm{TH}$, just as found on this study.

On this study, a slight improvement in the model adjustment was presented when including both independent variables (TH and $\mathrm{DBH}$ ) than in those that have it separated. On the other hand, models involving only one of them show a higher practicality in their usage. Thus, the usage of the model that employs only TH as independent variable is more convenient, considering that it can be measured more easily in this kind of trees, consequently reducing the error. Therefore, it is possible a wider usage of the model for biomass and carbon estimation in carbon inventories and nutrient dynamics.

Many models have been developed by transforming logarithmically the dependent and independent variables, which matches these findings (Hughes et al., 1999;
Chave et al., 2005; Segura and Kanninen, 2005; Andrade et al., 2008). This procedure allows linearizing data and avoiding variance heteroscedasticity, being an obvious and reasonable tool for such purposes (Mascaro et al., 2014). In the development of models, $\mathrm{R}^{2}$ is valid as a measure of adjustment or predictive value if the model is right as much in its deterministic aspect as its random part. However, this statistic must not be the only one to be considered, given that since an adjustment could be incorrect and result in a high $\mathrm{R}^{2}$ (Clutter et al., 1983; Sit and Poulin-Costello, 1994; Di Rienzo et al., 2009; Mascaro et al., 2011; Andrade et al., 2014).

The comparison of the model with the best adjustment of the current study with others from specialized literature permits to see its applicability, considering that some of these models are recommended as general and could be applied to the conditions of 

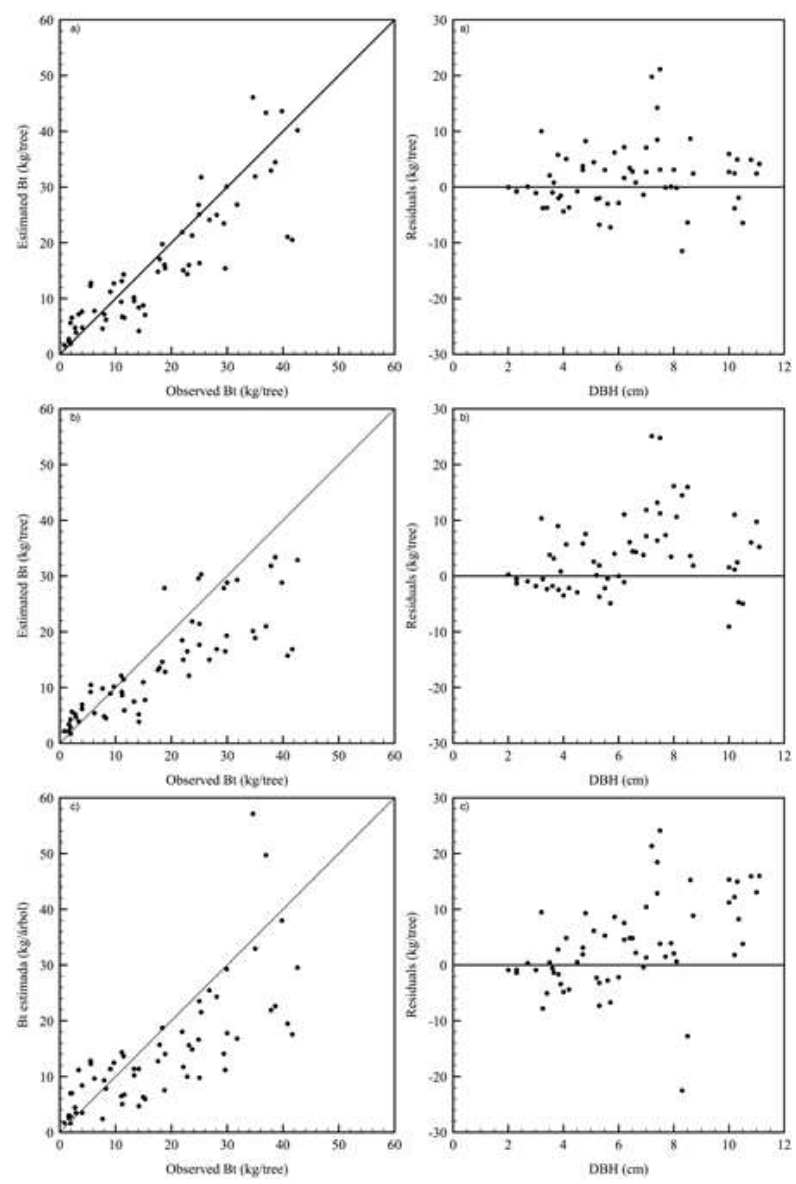

Figure 2 - Relationship between estimated and observed (measured) total aboveground biomass with the best-fit models in small trees $(\mathrm{DBH}<12 \mathrm{~cm})$ in forests of the Consejo Comunitario de la Cuenca del Bajo Calima, Buenaventura, Valle del Cauca, Colombia. Bt: total aboveground biomass; $\mathrm{DBH}$ : diameter at breast height. a) Eq. 4; b) Eq. 5; c) Eq. 6.

Figura 2-Relação entre a biomasa aérea total estimada e observada (medida) dos modelos de melhor ajuste em árvores pequenas $(D A P<12 \mathrm{~cm})$ em bosques do Consejo Comunitario de la Cuenca del Bajo Calima, Buenaventura, Valle del Cauca, Colombia. Bt: biomasa aérea total; A) Ec. 4; B) Ec. 5 ; C) Ec. 6 .

tropical wet forests of the Colombian Pacific. The development of local models to estimate aboveground biomass is a valuable tool for GHG mitigation projects (Brown et al., 1989; IPCC, 2006; Segura and Andrade, 2008), such as REDD+, since it allows improving estimations and increase carbon credits (IPCC, 2006; van Breugel et al., 2011).

Revista Árvore. 2018;42(2):e420209
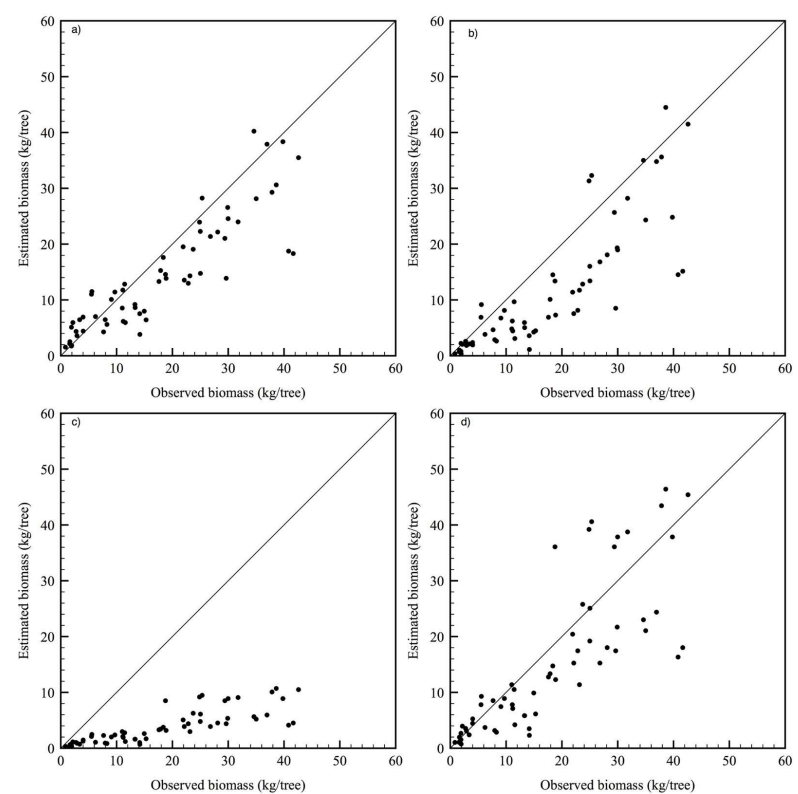

Figure 3 - Comparison between observed and estimated total aboveground biomass $(\mathrm{Bt})$ in small trees $(\mathrm{DBH}<$ $12 \mathrm{~cm}$ ) in forests of the Consejo Comunitario de la Cuenca del Bajo Calima, Buenaventura, Valle del Cauca, Colombia. a) This study (Eq. 4); b) Chave et al. (2005) (Eq. 1); c) Andrade et al. (2008) (Eq. 2) and d) Hughes et al. (1999) (Eq. 3).

Figura 3 - Comparação entre a biomasa aérea total (Bt) observada e estimada em árvores pequenas (DAP $<12 \mathrm{~cm}$ ) em bosques do Conselho Comunitário da Bacia do Baixo Calima, Buenaventura, Vale do Cauca, Colômbia. A) Este estudo (Ec. 4); B) Chave et al. (2005) (Ec. 1); C) Andrade et al. (2008) (Ec. 2) e D) Hughes et al. (1999) (Ec. 3).

The model generated on this study, for smalldiameter individuals ( $\mathrm{DBH}<12 \mathrm{~cm}$ ), complements the biomass and carbon estimations in very wet tropical forests that use models such as the ones from Chave et al. (2005) for individuals with $\mathrm{DBH} \geq 12 \mathrm{~cm}$. Specificity in the use of these multi-species models permits to improve reserve and carbon flux estimations of these forests that are highly diverse. Local multi-species allometric models for forests are scarcely reported, usually some are found but for big trees, just like the one by Fonseca et al. (2009), who developed it using 35 species from secondary forests in the Caribbean area of Costa Rica and the one by Segura and Kanninen (2005), which involved seven species from wet tropical forest. The model generated in this study allows estimating locally the total biomass of the minor-diameter 
trees in the conditions of the Bajo Calima, which is a useful tool that contributes to biomass and carbon fixation studies as option for climate change mitigation and nutrient cycling.

\section{CONCLUSIONS}

Dasometric variables of TH and DBH obtained a high correlation with aboveground biomass, which grated the development of allometric models with good adjustment. In the case of small trees, model based exclusively on $\mathrm{TH}$ show significant practical advantages in their applicability, given that the measurement of this variable has little error and is easier to perform.

The comparison of the models developed in this study to those ones found on previous scientific literature ratifies the importance of generating such tools at a local scale. Multi-species allometric models generated are an important tool in order to quantify the stock of aboveground biomass and carbon of these forests in a more reliable way and formulate strategies and projects of sustainable land use.

\section{ACKNOWLEGEMENTS}

The authors express their most sincere thanks to the Comité Central de Investigaciones de la Universidad del Tolima for the financial support granted to the Project No, 1050213 from the "Producción Ecoamigable de Cultivos Tropicales (PROECUT)" Research Group. Also, to the communities of the Consejo Comunitario de la Cuenca del Bajo Calima for their attendance and assistance to carry out this study.

\section{REFERENCES}

Álvarez E, Duque A, Saldarriaga J, Cabrera K, De Las Salas G, Del Valle I, et al. Tree above-ground biomass allometries for carbon stocks estimation in the natural forests of Colombia. Forest Ecology and Management. 2012;267(1):297-308.

Andrade H, Segura M, Somarriba E, Villalobos M. Valoración biofísica y financiera de la fijación de carbono por uso del suelo en fincas cacaoteras indígenas de Talamanca, Costa Rica. Revista Agroforestería en las Américas. 2008;(46):45-50.

Andrade H, Segura M, Forero L. Desarrollo de modelos alométricos para volumen de madera, biomasa y carbono en especies leñosas perennes: Conceptos básicos, métodos y procedimientos.
Ibagué: Sello Editorial Universidad del Tolima; 2014.

Banco Mundial. "Por qué los bosques son fundamentales para el clima, el agua, la salud y los medios de subsistencia," marzo 2016. [En línea]. Disponible en: http://www.

bancomundial.org/es/news/feature/2016/03/18/ whyforests-are-key-to-climate-water-health-andlivelihoods

Brown S, Gillespie A, Lugo A. Biomass estimation methods for tropical forests with applications to forest inventory data. Forest Science. 1989;35(4):881-902.

Chave J, Andalo C, Brown S, Cairns M, Chambers J, Eamus D, et al. Tree allometry and improved estimation of carbon stocks and balance in tropical forests. Oecología. 2005;145(1):87-99.

Clutter J, Fortson J, Pienaar L, Brister G, Bailey R. Timber management: A quantitative approach. New York: Wiley; 1983.

Di Rienzo J, Casanoves F, González L, Tablada E, Díaz M, Robledo C, et al. Estadística para las ciencias agropecuarias. Córdoba: Brujas; 2009. 372 p.

FAO. "La gestión de los bosques ante el cambio climático,”2010. [En línea]. Disponible en: http:// www.fao.org/ docrep/014/i1960s/i1960s00.pdf

Field CB, Maccracken S, Mastrandrea MD, Levy AN, Bilir TE, Barros VR, et al. Cambio climático 2014 Impactos, adaptación y vulnerabilidad. Suiza: IPCC; 2014.

Fonseca W, Alice F, Rey J. Modelos para estimar la biomasa de especies nativas en plantaciones y bosques secundarios en la zona Caribe de Costa Rica. Bosque. 2009;30(1):36-47.

Hughes RF, Kauffman JB, Jaramillo VJ. Biomass, carbon, and nutrient dynamics of secondary forest in a humid tropical region of México. Ecology. 1999;80(6):1892-1907.

Ilyas S. Allometric equation and carbon sequestration of Acacia mangium willd. in coal mining reclamation areas. Civil and Environmental Research. 2013;3(1):8-16.

Revista Árvore. 2018;42(2):e420209 
Instituto de Hidrología. Meteorología y Estudios Ambientales - IDEAM. Sistemas de información. Petición Información Radicado 20160418171008. 2016.

Intergovernmental Panel on Climate Change IPCC. Guidelines for National Greenhouse Gas Inventories. Tokio: National Greenhouse Gas Inventories Programme; 2006.

Lozano L, Gonzalez J. Bajo Calima: riqueza biológica y cultura afectada por la extracción de maderas tropicales. Lebret. 2011(3):205-220.

Martínez H. Análisis ecológico silvicultural, con fines de manejo, del bosque secundario de la vereda Las Brisas, Buenaventura [tesis] Valle del Cauca, Colombia. Santiago de Cali: Universidad del Valle; 2007.

Mascaro J, Litton CM, Hughes FR, Uowolo A, Schnitzer SA. Minimizing bias in biomass allometry: model selection and log-transformation of data. Biotropica. 2011;43:649-653.

Mascaro J, Litton CM, Hughes RF, Uowolo A, Schnitzer SA. Is logarithmic transformation necessary in allometry? Ten, one-hundred, onethousand-times yes. Biological Journal of the Linnean Society. 2014;111:230-233.

Nelson A, Weiskittel A, Wagner R, Saunders M. Development and evaluation of aboveground small tree biomass models for naturally regenerated and planted species in eastern Maine, U.S.A. Biomass and Bioenergy. 2014;68:215-227.

Picard N, Saint-André L, Henry M. Manual for building tree volume and biomass allometric equations: from field measurement to prediction. Rome: Food and Agricultural Organization of the United Nations and Montpellier, Centre de Coopération Internationale en Recherche Agronomique pour le Développement; 2012. 215p.
Programa de las Naciones Unidas para el Desarrollo - PNUD. Los afrocolombianos frente a los objetivos de desarrollo del milenio, 2010b. [acceso en: 17 sep 2016]. Disponible en: http:// www.undp.org/content/dam/colombia/docs/ODM/ undp-co-odmafrocolombianos-2012.pdf.

Sanquetta CR, Behling A, Dalla A, Augusto S, Pscheidt H, Ruza M, et al. Estoques de biomassa e carbono em povoamentos de acácia-negra em diferentes idades no Rio Grande do Sul. Scientia Forestalis. 2014;42(103):361-370.

Segura M, Kanninen M. Allometric models for tree volume and total aboveground biomass in a tropical humid forest in Costa Rica. Biotropica. 2005;37(1):2-8.

Segura MA, Andrade HJ. ¿Cómo construir modelos de volumen, biomasa o carbono en especies leñosas perennes? Agroforestería en las Américas. 2008(46):89-96.

Sit V, Poulin-Costello M. Catalogue of curves for fitting. Biometrics Information. Handbook Province of British Columbia: Forest Science Research Branch Ministry of Forests; 1994.

van Breugel M, Ransijn JM, Craven D, Bongers F, Hall J. Estimating carbon stock in secondary forests: Decisions and uncertainties associated with allometric biomass models. Forest Ecology and Management. 2011;262:1648-1657.

Verified Carbon Standard - VCF. Proyecto REDD+Bajo Calima y Bahía Málaga, Versión 3, 2015. [acceso en: 17 sep 2016]. Disponible en: http://www.v-c-s.org/sites/cs.org/files/ BCBM\%20PDD_Spanish \%20Summary_v1.6.pdf.

Zanne AE, Lopez-Gonzalez G, Coomes DA, Ilic J, Jansen S, Lewis SL, et al. Global wood density database, Dryad, 2009. [acceso en: 17 feb 2017]. Disponible en: http://hdl.handle.net/10255/ dryad.235. 